\title{
良性骨芽細胞腫の1例
}

南雲正男・倉地洋一・大野邦博

原利通・曾田忠雄・伊藤秀夫

\section{A case of benign osteoblastoma.}

\author{
Masao Nagumo Youichi KurachI $\cdot$ Kunihiro Ohno \\ Toshimichi HARA - Tadao Soda - Hideo Ito
}

緒

言

䫑骨の良性骨芽細胞腫はきわめて稀といわれておう， 本邦に和ける症例報告は赤坂ら および伊藤ら ぞれ1例のみである．われわれの教室では赤坂らの報告 後にさらに 3 例を経験したが，今回はそのうち，臨床像 からは悪性の骨腫瘍が疑われたために䫇切除を行ない, 摘出腫瘍の組織学的検查で良性骨芽細胞腫之診断された 症例について，その概要を報告する。

\section{症例}

\section{患者： 37歳 男性}

初診 : 昭和 48 年 3 月回

主訴 : 左側下频白歯部の腫脤

家族歴および既往歴：特記すべき事項なし．

現病歴：約 4 カ月前の昭和 47 年11月ころに $\overline{7}$ の動摇に 気付き，12月末に某歯科医で歯槽䐬漏と診断され，同歯 を拔去された，抜药窝から肉芽様の組織がもり上がり， 徐々に增大してきたので，翌年 1 月に切開されたが排脤 はなく，その後す腫脹部が増大してきたので， 3 月回日 に当科を紹介されて来院した.

現症：体格，栄盖共浪好で，全身的には健 康であ り，血液，血清および尿についての臨床検查でる特に異 常はみられない。

顔貌は僅かに非対称性で，左側大日歯にに相当する下 顠体部が僅かと腫脹している。顎下括よび頸部のリンパ 節は触知されない。

口腔所見は写真 1 のようで，六はなく，|5から翼突下

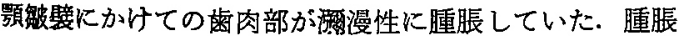

東京医科齿科大学齿学部第二口些外科学教室

（主任：伊藤秀夫教授）

2 nd Department of Oral Surgery, School of Dentistry,

Tokyo Medical and Dental University,

(Chief : Prof. Hideo Ito)

受付 : 昭和 51 年 7 月 6 日

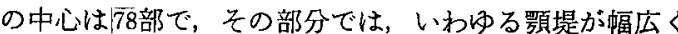
むりあがって扣り，上顎大曰菌咬合面の压痕が印されて いた．腫脹部は弾性硬で，軽微な王痛がある．被復粘膜 には特に異常はなく、一部か゚発赤しているのみであっ た。

$\mathrm{X}$ 楾所見：腫脹部に一致して，すなわち， 6 部から下 顎枝の前緑部にかけて，下䫟骨の上部が全体的にスリガ ラス様の像を示して扣り，健康な部分との境界は不鮮明 である. その中央の $\overline{7} 8$ 部に直径約 $1.5 \mathrm{~cm}$ の半円形のも り上がった骨吸収像を示す部分があり，吸収像の上部に は calcific shell 様の細い不透過線が扣ぼろげながらる 認められ，またその内部には，不規則な形の小石灰化物 が斑紋状にみられた。向の橉槽骨の中央から上部は消失 しており，また根尖部まで荬根膜腔が抬大しているが， 函根吸収の像は著明でない（写真 2，3 および 4-b).

組䅧学的検查：3月口日执よび 4 月口日の 2 回，腫脹 の中央部から組織片を採取して，組織学的検查を依頼し た．本学口腔病理学教室からの報告は, “骨茅細胞と思 われる細胞の增殖からなる腫瘍で，瘇瘍内には類骨の形 成とそれへの石灰化がみられ，かなり多量の未熟な骨質 が形成されている（写真 5 执よび写真 6).この所見が全

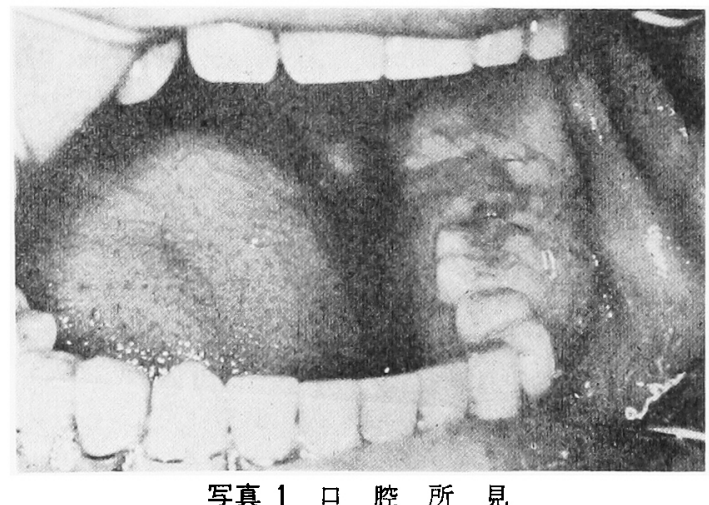

写真 1 口腔 所 見 


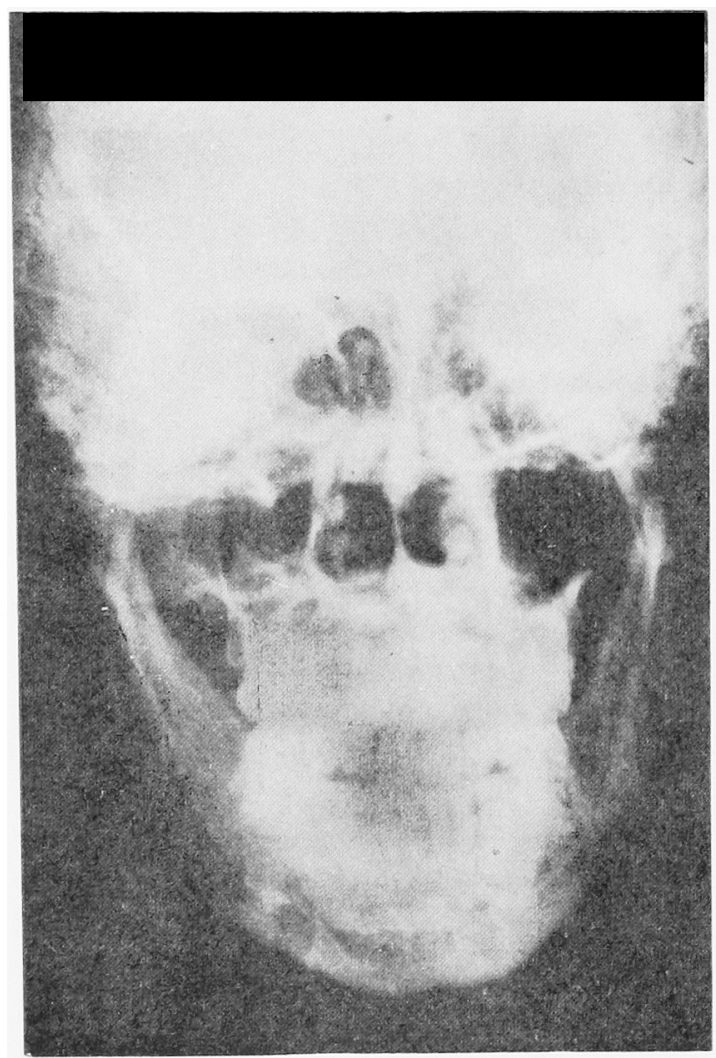

写真 $2 \mathrm{X}$ 線 所 見

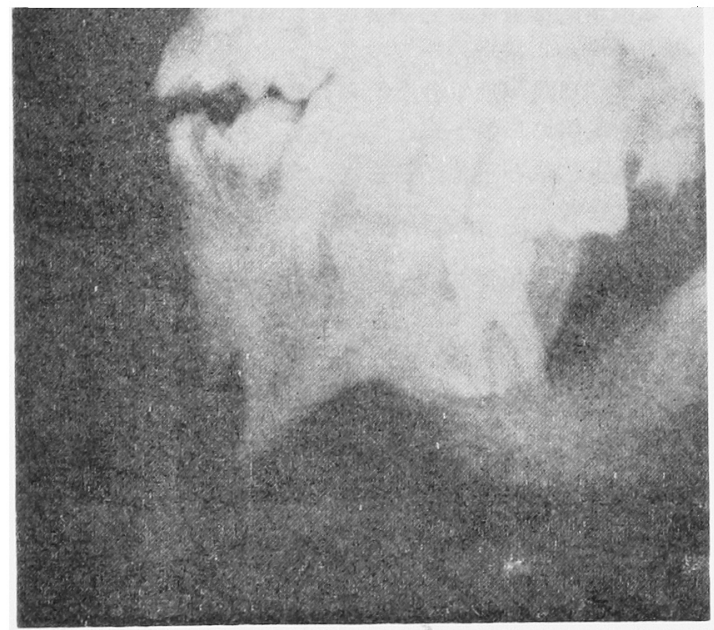

写真 $3 \times$ 線所 見

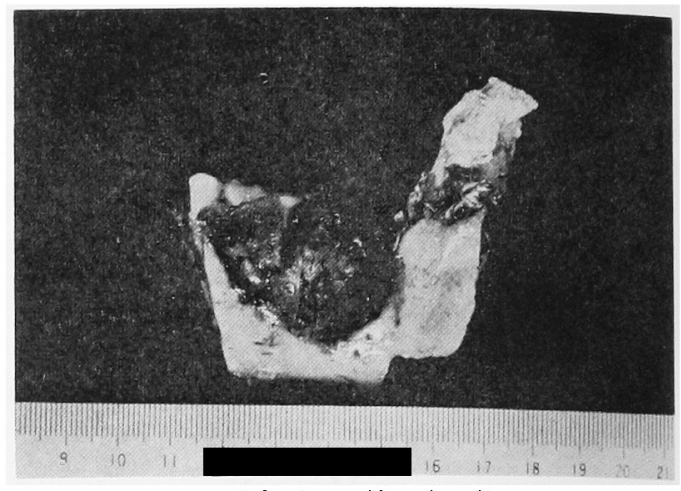

写真 4-a 摘 出 物

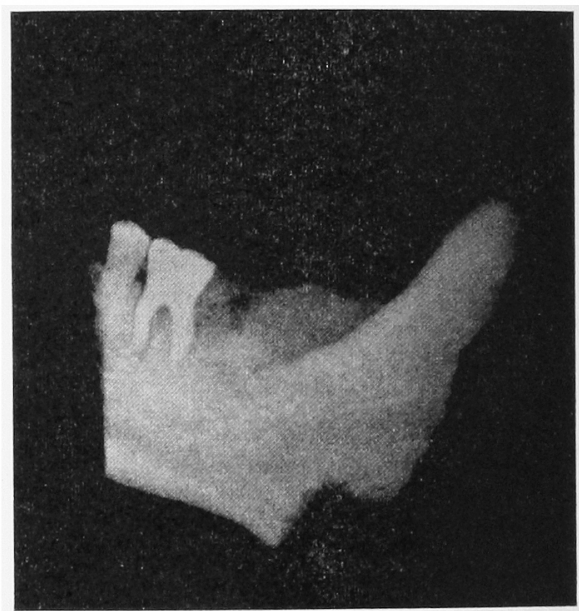

写真 4-b 同 X 楾所見

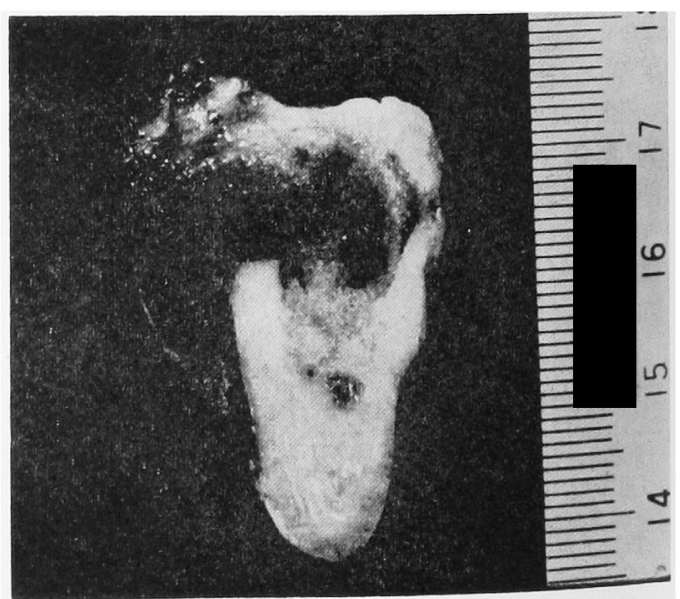

写真 4-c 同割 面 
体像であれば良性骨芽細胞腫であろう，とのことであっ た.

治療：病理組織学的所見は上記のようであったが，臨 床的経過で腫瘤の増大が早いこと，X線像で境界が明瞭 でないことなどから，骨原性の悪性腫瘍の疑いも否定で きなかったので顎切除の方針が決定された．5月18日に， 全身麻酔下で, $\mid 4$ の遠心と, 下颗枝の後縁から約 $2 \mathrm{~cm}$ の所で下顎骨を切断して腫瘍を除去し，生じた骨欠損部 飞対しては，腸骨稜より骨片を採取して骨移植を行なっ た. 術後経過は良好で, 再発の徵候は全くみられない。

切除物の所見 : 下顎骨の上部を占める腫瘍の大きさは $2.5 \times 3.5 \times 4.0 \mathrm{~cm}$ で, 賽側面への膨隆は軽度であるが, 舌側面には半球状に大きく膨隆しており, その下端は下 䫇下縁から約 $0.6 \mathrm{~cm}$ のところまで達していた（写真 4a). 頓舌的割面をみると，腫瘍は充実性で，一部は暗赤 色，大部分は灰白色を呈して扮り，内部に石灰化組織が みられた．下顎骨の深部に增殖している腫瘍の境界はあ まり鮮明でなかった．しかし，舌側面に膨隆した腫瘍と 下顎骨の舌側表面との境界は明瞭であった（写真 4-c).

切除腫瘍の病理組織学的所見 : 腫瘍は顎骨においては 下方に増殖して, その先端は下顎管の近くまで達してい る. 増殖はどちらかといえば膨張性ではあるが，明らか な被膜はみられない，一方，下顎骨上部から舌側の骨皮 質に沿って増殖している部分では, 腫瘍と周囲組織との 境界はかなり明膫である. 腫瘍内にはいくつかの拡張し た腔があり，血液を入れているが，その壁に，通常の血 管壁の構造は認められない. 腫瘍組織の所見は試験切除 標本のそれと同様で，細胞成分に富み，不規則な梁状な いしは塊状の硬組織を形成する腫瘍巣が線維性組織の間 に存在していた. 硬組織は全体的に石灰化が弱く, 幼若 は類骨梁の所見を呈していた（写真 5 および 6 )，なお， 下顎骨の舌側面外方に増殖した部分は線維性組織と線維 骨梁からなっていた(写真 7).

以上の組織学的所見から，本腫瘍は良性骨芽胞細腫と 診断された.

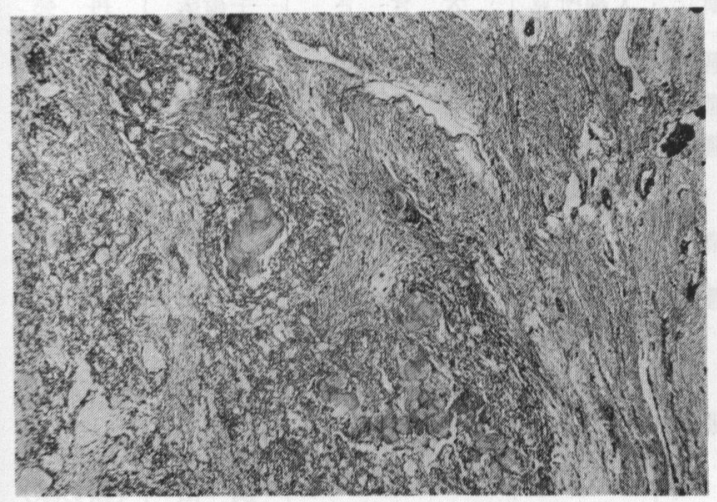

写真 5 腫瘍上部の組織像 $(\times 50)$
考案

良性骨芽細胞腫 (benign osteoblastoma) は Jaffe $\mathrm{e}^{3)}$ (1956)および Lichtenstein ${ }^{4}$ (1956) が命名し,独立した 骨腫瘍として分類したもので，それ以前は osteoblastic osteoid tissue forming tumor ${ }^{5)}$, osteogenic fibroma ${ }^{6}$,

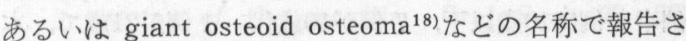
れていたよらである.本腫瘍の組織学的特徵は骨芽細胞 様細胞の増殖と梁状の類骨組織の形成であるが，命名の 理由について, Jaffe ${ }^{3)}$ およ゙ Lichtenstein ${ }^{4)}$ はそれぞ れ組織学的には骨原性肉腫とまぎらわしい点もあるが, 本来は良性腫瘍であり，悪性の経過をとるるのとは区別 する必要があるからと述べている。

本腫瘍は骨腫瘍の中でもかなり稀なもののようで, 本 邦では，登録されている骨腫瘍 13, 299 例のうちの 34 例 $(0.3 \%)$ にすぎない ${ }^{8}$. 発生部位は主として長管骨と脊椎 骨であり，顎骨には少なく，天児8)の調査では34 例中の 5 例, Byers の調査 ${ }^{9)}$ では 112 例中の 2 例, また Dahlin らの調査 ${ }^{7)}$ では 28 例中の 2 例が上顎骨または下顎に発生 したるのとして記録されている.したがって, 症例報告 形式の文献は少なく，われわれが渉猟できたのは上頢 2

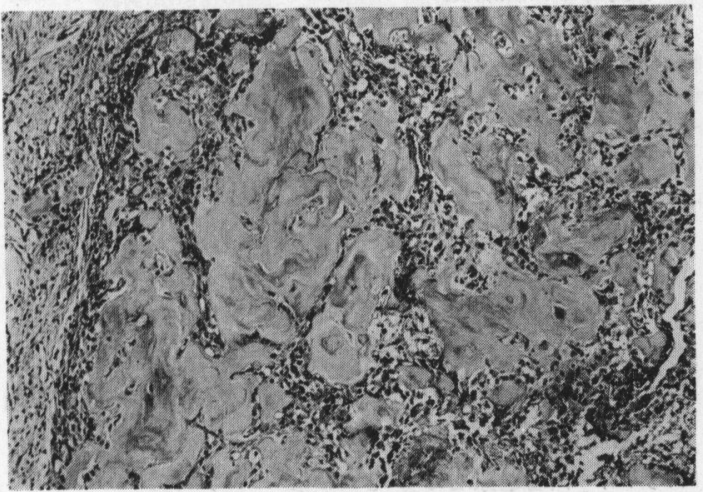

写真 6 腫瘍の組織像 $(\times 120)$

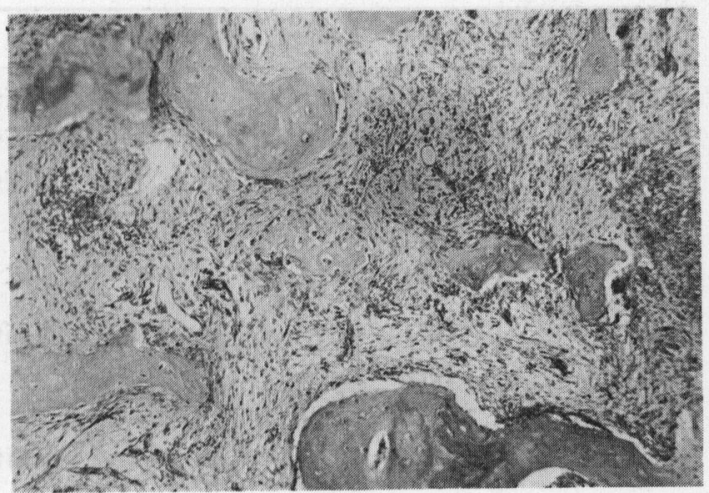

写真 7 顎骨舌側面の外側に増殖した部分の組織像 $(\times 120)$ 


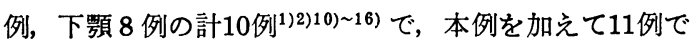
ある(表 1).

患者の年龄は比較的若い人が多いようで, Lichtenstein $5^{17)}$ によると, 16例中 12 例が 7 歳から 20 歳の間, 4 例がそれ以後の成人で, 最年長は78歳となっている. 靧領域の本腫瘍にも同様の傾向がみられ，表にあげた11 例中 2 例は10歳以下, 7 例が 10 歳代, 1 例が 21 歳で, 本 例のみが37歳であった. なお, 男女別は 9 例が男性, 2 例が女性で, Lichtenstein ら ${ }^{17)}$ および Dahlin $5^{18)}$ と同 じ傾向であった.

本腫場は骨の内部に発生して緩慢に発育し，発見時の 大きさは長径 $2 \sim 3 \mathrm{~cm}$ のものが多いといわれているが， なかには Jaffe $\mathrm{e}^{8)}$ の記載のように $6 \times 6.5 \times 10 \mathrm{~cm}$ に達す るものもある. 本例は $2.5 \times 3.5 \times 4.0 \mathrm{~cm}$ で, 顎骨に発 生したものとしては大きいほうであるが，特異な点はむ しろその発育状態であった，すなわち，本腫湯の発育は 一般に骨内であって，骨を破って外部にまで増大する症 例はあまり多くないようである。 しかし，本例は下顎骨 の比較的上部に発生したためか，前記のように，䫟堤部 から舌側面の外側に大きな腫瘍塊を形成しており，骨の 深部に向かっての発育はあまり顕著ではなかった.

本腫場のX線所見については Pochaczevsky ら ${ }^{19)}$ の詳 細な記載がある。それによると，腫瘍のX線像の主体は 骨溶解性の変化で，その内部に骨ないし類骨の形成像が いろいろな程度に存在するとのことであり， Jaffe $\mathrm{e}^{\mathrm{s}}$ 扰よ び Lichtenstein ${ }^{4}$ す本質的なX線像は骨溶解性であると 述べている. 一般に, 形成初期の腫瘍は骨梁ないしは類 骨組織が少なく，X線的に透過性の病像を示すが，腫汮 が成熟するにつれて類骨梁が增加し，石灰化が進むので， 次第に不透過像が現われてくると理解されている ${ }^{3220)}$.

しかし, 石灰化組織の多少は腫瘍の新旧とは関係なく, むしろ腫瘍細胞の活性によるとの見解もある ${ }^{11)}$. 頼骨発 生のるのは, 赤坂ら ${ }^{11}$ 扰よび Kent $5^{12)}$ が指摘している ように，不透過像を示するのが多いようである.
腫瘍と骨健康部との境界は一般に明瞭であり，骨皮質 を突破して軟組織に增大した部分でも，その表面は “calcific shell”で被われていると言われている8)4)19). 本例では, 78 (欠損)部に, 約 $1.5 \mathrm{~cm}$ の半円形のるり上 がった透過巣がみられ，その内部には小石灰化物の像, 円周には “calcific shell”を思わせる細い線状の不透過 像がみられたが，基底部と顎骨との境界は不明瞭であ り，またそれを中心として額骨の上部が全体的にスリガ ラス様の像を呈しており, 顎骨の健康部との境界は不鮮 明であった(図 4-b).このスリガラス様の像は切除標本 についての検討で，舌側面に増殖した腫瘍塊によること が判明したが，手術前のX線写真では，以上のことから 骨原性の悪性腫湯が疑われる像之解釈された。

本腫瘍と類症鑑別を要する疾患として，顎骨の場合に は，類骨腫，セメント質腫，巨細胞腫扰よび骨原性肉腫 などが挙げられている。このうち，類骨腫は通常 $1 \mathrm{~cm}$ 以下であり, 疼痛を伴う, 皮質の硬化が強く“nidus” と 呼ばわる像がみられる等の特徵があり ${ }^{21) ， ま た セ メ ン ト ~}$ 質腫には歯根と密着しているのが特徴であるので，それ らとの鑑別診断はさほど困難ではない，最も重要なのは 骨原性肉腫であって, Lichtenstein ${ }^{4)}$ が指摘しているよ らに, 試験切除によって得られた小組織片の場合は正確 な診断が困難なことがあるので，本症例のように臨床像 から悪性腫場が疑われる場合には特に注意すべきである 万.

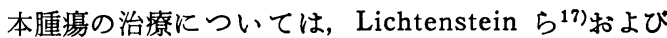
Dahlin ら ${ }^{18)}$ は局所的な掻爬のみで治瘾が得られると述

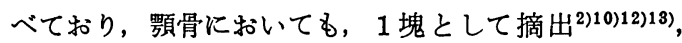

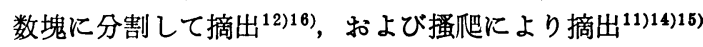
などの処置がとられている. しかし，これらの除去方法 とは関係なく，4 例(10)14)16) が再発しており，とくに Remagen $5^{16)}$ の症例は，最初小塊に分けて摘出された が再発し, 再発腫湯に対しては顎切除が行なわれてい る. 本症例の場合は, 上述のように試験切除標本では良

表 1 䫟骨の良性骨芽細胞腫の報告症例

\begin{tabular}{|c|c|c|c|c|c|c|c|c|}
\hline 報 告 者 & 発表年 & 年令と性 & 部 位 & 主 訴 & $\mathrm{X}$ 線所見 & 大きさ & 手術法 & 再 発 \\
\hline Borello $5^{10)}$ & 1967 & 21 , ิิ & 上 䫅 & 無痛性腫脹 & 透過像 & $2 \times 2 \times 3 \mathrm{~cm}$ & 摘 出 & + \\
\hline Kramer ${ }^{11)}$ & 1967 & $6, \quad \%$ & 下 買 & 有痛性腫脹 & " & $?$ & 掻爬 & - \\
\hline Kent $5^{12)}$ & 1969 & 13 , ㅇ & 上 類 & 無痛性腫脹 & 不透過像 & $3 \times 4 \mathrm{~cm}$ & 摘 出 & - \\
\hline Kopp ${ }^{13)}$ & 1969 & 19 , ิ & 下 䫫 & ? & 透過像 & $2 \times 2 \times 2 \mathrm{~cm}$ & $" \prime$ & - \\
\hline 赤坂・ 1) & 1971 & 18 , ô & " & 疼 痡 & 不透過像 & $1.5 \times 2 \mathrm{~cm}$ & $\begin{array}{l}\text { 分 割 } \\
\text { 摘 }\end{array}$ & - \\
\hline 伊藤ら ${ }^{2)}$ & 1971 & 18 , ô & " & 有痛性腫脹 & " & $2.8 \times 3 \mathrm{~cm}$ & 摘 出 & + \\
\hline Smith ${ }^{14)}$ & 1972 & 7 , $\delta$ & " & " & " & ? & 蛋爬 & + \\
\hline Brady $^{15)}$ & 1972 & 19 , ô & " & $" \prime$ & 透過像 & $?$ & " & - \\
\hline$" \prime$ & 1972 & $14, \hat{\delta}$ & " & 無痛性腫脹 & ? & ? & 摘 出 & - \\
\hline Remagen $5^{16)}$ & 1975 & $15, \hat{o}$ & " & " & 不透過像 & $2 \times 2 \times 2 \mathrm{~cm}$ & $\begin{array}{l}\text { 分 割 } \\
\text { 摘 }\end{array}$ & (類切除) \\
\hline
\end{tabular}


珄骨芽細胞瘇が考虑されたが，発育経過およびX線像か ら，臨床的には骨原性の悪性腫瘍の可能性も否定できな かったので，頻切除術を適用したが，術後経過は良好で あり， 3 年 6 カ月後の現在，再発の峌候は全くみられな い.な怙本例の䫇骨内に增殖している腫痬には明らかな 被膜がなく，骨喵組織との境界が明瞭でない部分がみら れたので，腫湢を摘出ないしは提爬除去する場合でも， 周囲の骨組織の一層を削除しておくことが望ましいよう に思われる。

\section{結論}

われわれは下顎骨の内部から外部にかけて発有した良 性骨芽細胞腫の症例を経験したので，その臨床像，組織 学的所見および治療の概要を報告し, 併せて文献に記载 された10例についても考察した。

\section{文献}

1）赤坂鞒子，他：下顎骨飞発生した良性骨芽細胞 腫. 口外誌 $20: 1401971$.

2）伊藤辉夫，他：珍しいBenign osteoblastoma の 再発例について. 口科誌 $20: 8471971$.

3) Jaffe, H. L.: Tumors and Tumorous Conditions of the Bones and Joints. Lea and Febiger, Philadelphia, 1958 p. 107

4) Lichtenstein, L.: Benign Osteoblastoma. A category of Osteoid and Bone Forming Tumors other than Classical Osteoid Osteoma, which may be mistaken for Giant-Cell Tumor or Osteogenic Sarcoma. Cancer 9 : 10441956.

5) Jaffe, H. L., and Mayer, L.: An osteoblastic osteoid tissue-forming tumor of a metacarpal bone. Arch Surg 24:550 1932.

6) Golding, J. S. R., and Sissions, H. A : Osteogenic fibroma of bone : a report of two cases. J Bone \& Joint Surg 36-B : 4281954.

7) Dahlin, D. C.: Bone tumors, ed 2, Charles C.
Thomas, Springfield, 1967, p. 70 .

8）天児民和：骨・関節 $X$ 線診断図䍀吕，骨腫晹，金 原出版, 東京, 1968114 面.

9) Byers, P. D.: Solitary benign osteoblastic lesions of bone. osteoid osteoma and benign osteoblastoma. Cancer 22:43 1968 .

10) Borrello, E. D., and Sedano, H. O.: Giant osteoid ostema of the maxilla. Oral Surg 23:563 1967.

11) Kramer, H. S.: Benign osteoblastoma of the mandible. Oral Surg 24:842 1967.

12) Kent, J. N., Castro, H.F., and Girotti, W. R.: Benign osteoblastoma of the maxilla. Oral Surg 27:209 1969.

13) Kopp, W.K.: Benign osteoblastoma of the coronoid process of the mandible. J Oral Surg $27: 6531969$.

14) Smith, N. H. H.: Benign osteoblastoma of the mandible. J Oral Surg 30:288 1972.

15) Brady, C. L., and Browne, R. M.: Benign osteoblastoma of the mandible. Cancer 30:329 1972.

16) Remagen, $W$. and Prein, J. : Benign osteoblastoma. Oral Surg $39: 2791975$.

17) Lichtenstein, L. and Sawyer, W. R. : Benign osteoblastoma. J Bone and Joint Surg : 46-A: 7551964.

18) Dahlin, D. C. and Johnson, E. W. : Giant osteoid osteoma. J Bone and Joint Surg. 36-A : 559 1954.

19) Pochaczevsky, R., Yen, Y.M. and Sherman, R. $S$. : The roentgen appearance of benign osteoblastoma. Radiology $75: 4291967$

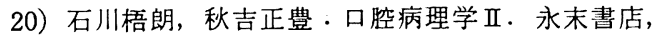
京都, 1969，979 頁.

21) Greene, G. W., Natiella, J. R. and Spring, P. N. : Osteoid osteoma of the jaws. Oral Surg 26: 3421968. 